\title{
January 20-24
}

Annual Conference of the Association for Educational Communications and Technology (AFCT) in Dallas, Texas, USA.

Information: AFCT, 1126 16th Street, N.W., Washington, D.C. 20036, USA.

\section{January 25-30}

Second international week of languages and cultures "Expo-Languages" in Paris, France.

Information: Comite des Expositions de Paris, 7, rue Copernic, F-75782 Paris Cedex 16, France.

\section{February 14-17}

Seventh European Congress Fair for Technical Communications (ONI INF 84) in Berlin, Federal Republic of Cermany.

Information: ONI INF, Postfach 1008 66, D-5620 Velbert 1, Federal Republic of Germany.

\section{February 27-29}

Symposium "Cerman as a Foreign Language" of the International Association of Applied Linguistics in St. Gallen, Switzerland.

Information: Professor Dr. W. Kuehlwein, University, Postfach 3825, D-5500 Irier, Federal Republic of Germany.

\section{March 6-11}

Fifteenth Annual Conference of Teachers of English to Speakers of Other Languages (TFSOL) in Houston, Texas, USA.

Information: TFSOL Central Office, 202 D.C. Transit Building, Georgetown University, Washington, D.C. 20057, USA.

\section{March 13-16}

Annual Meeting of the Institute for the German Language in Mannheim, Federal Republic of Germany.

Theme: Language Culture.

Information: Institut fuer deutsche Sprache, Friedrich-Karl-Strasse 12, D-6800 Mannheim, Federal Republic of Cermany.

March 20-24

International Educational Materials Fair Didacta in Basle, Switzerland.

Information: Secretariat DIDACTA, Postfach, CH-4021 Basel, Switzerland. 


\section{March 29-31}

Silver Jubilee Meeting of the Linguistic Association of Great Britian in Hull, United Kingdom.

Information: N. Wheeler, Department of Linguistics, University, P.O. Box 147, Liverpool L69 33X, United Kingdom.

\section{April 2-4}

Colloquium of the Council of Europe in Strasbourg, France.

Theme: 1984 - Myths and Realities. Man, the State and Society in Question. Orwell revisited.

Information: F. Rosenstiel, Council of Europe, BP 431 R6, F-67006 Strasbourg, France.

\section{April 12-15}

Northeast Conference on the Teaching of Foreign Languages in New York City, USA.

Information: J. Dodge, Box 633, Middlebury, Vermont 05753, USA.

\section{April 16-18}

National Congress of the West Cerman Modern Language Association in Passau, Federal Republic of Cermany.

Information: W. Christ, Beethovenstrasse 4, D-8502 Zirndorf, Federal Republic of Germany.

\section{April 23-27}

Nineteenth Seminar of the Regional Language Centre (RFLC) in Singapore, Republic of Singapore.

Theme: Communicative language teaching.

Information: Miss Yolanda Beh, RFLC Building, 30 Orange Grove Road, Singapore 1025, Republic of Singapore.

\section{April 24-27}

Seventh European Meeting on Cybernetics and Systems Research in Vienna, Austria.

Information: Studiengesellschaft fuer Kyhernetik, Schottengasse 3, A-1010 Wien 1, Austria.

\section{April 25-27}

Fifteenth International Congress of the International Association of Teachers of English to Speakers of Other Languages (IATFFL) in Groningen, The Netherlands.

Theme: Ways in which teachers teach and learners learn.

Information: Mrs. B. Thomas, 87 Bennels Avenue, Tankerton, Whitstable, Kent CT5 2HR, United Kingdom. 
April 26-28

Central States Conference on the Teaching of Foreign Languages in Chicago, Illinois, USA.

Information: G.l. Ervin, Department of Slavics, Ohio State University, Columbus, Ohio 43210, USA.

May 11-13

Conference of the Pacific Northwest Council on Foreign Languages in Missoula, Montana, USA.

Information: R. Verzasconi, Department of Foreign Languages and Literatures, Oregon State University, Corvallis, Oregon 97331, USA.

May 14-17

International Conference on Communications in Eindhoven, The Netherlands.

Theme: Innovative Research and Applications of Telecommunications.

Information: Philips Research Laboratories, P.O. Box 218, NI-5600 MD Findhoven, The Netherlands.

May 21-25

Seventeenth Colloquim of AIMAV (Association Internationale pour la Recherche et la Diffusion des Methodes Audio-Visuel-les et Structuro-Clobales) on the teaching of Russian in Europe in Chent, Belquim.

Information: AIMAV, University, Blandijnberg 2, B-9000 Gent, Belgium.

\section{May 25-26}

Interdisciplinary Colloquium on Jean Bodin in Angers, France.

Information: Georges Cesbron, Haute Perche, Saint-Melaine-SurAubance, F-49320 Brissac-Quince, France.

\section{June 14}

Conference of the Association for the Advancement of Baltic Studies in Montreal, Canada.

Information: J. Gaigulis, 231 Miller Road, Mahwah, New Jersey 07430, USA.

\section{June 25-28}

Fifth International Phonology Meeting in Eisenstadt, Austria.

Information: Institute for Linguistics, Luegerring I, A-1010 Wien, Autria.

\section{June 25-August 3}

Teachers of English to Speakers of Other Languages (TESOL) Summer Institute in Corvallis, Oregon, USA.

Information: K. Drobnic, English Language Institute, Oregon State University, Corvallis, Oregon 97331, USA. 
June 28-July 1

Third Conference on Uralic Phonology in Eisenstadt, Austria.

Information: Institut fuer Finno-Ugristik, Berggasse 11/1/2, A-1090 Wien, Austria.

July 3-6

Fifth World Congress of the French Association of Comparative Education (AFFC) in Paris, France.

Theme: Dependence and Interdependence in Education.

Information: AFFC Congress Committee, 11, rue Pierre-Demours, F-75017 Paris, France.

July 15-20

Sixth World Congress of the International Federation of Teachers of French (FIPF) in Quebec, Canada.

Theme: Living French - Dialogue of Cultures and Individual Development.

Information: FIPF, Secretariat, I, Avenue Leon Journault, F-92310 Sevres, France.

\section{July 16-20}

Fifth International Conference on Methods in Dialectology in Victoria, British Columbia, Canada.

Information: H.J. Warkentyne, Department of Linguistics, University, Victoria, British Columbia V8W 2Y2, Canada.

\section{July 21-28}

Sixty-ninth World Congress of Esperanto in Vancouver, Canada. Information: World Association of Esperanto, Nieuwe Binnenweg 176, NL-3015 BJ Rotterdam, The Netherlands.

\section{August: dates to be announced}

Fifteenth Colloquium of AIMAV (Association Internationale pour la Recherche et la Diffusion des Methodes Audio-Visuel-les et Structuro-Clobales) on creativity in language teaching in Sao Paulo, Brazil.

Information: AIMAV, University, Blandijnberg 2, B-9000 Cent, Belgium.

\section{August 5-10}

Seventh World Congress of the International Association of Applied Linguistics (AILA) in Brussels, Belgium.

Theme: The Contribution of Applied Linguistics to International Understanding.

Information: Professor Dr. J. Nivette, AlLA World Congress, ITO/VUB, University, Pleinlaan 2, B-1050 Brussels, Belgium. 


\section{August 13-17}

Fifteenth International Congress on Family Name Research in Leipzig, German Democratic Republic.

Theme: The Family Name in Language and Society. Information: Sektion Theoretische und Angewandte Sprachwissenschaft, University, Karl-Marx-Platz 9, DDR-7010 Leipzig, German Democratic Republic.

\section{August 17-23}

Tenth World Congress of the International Federation of Translators (FIT) in Vienna, Austria.

Theme: Translators and their Position in Society. Information: FIT World Congress, Postfach 80, A-1107 Wien, Austria.

\section{August 24-28}

Seventh International Joint Conference on Artificial Intelligence (IJCAI) in Vancouver, Canada.

Information: F. Sauter, ZWD, Zi, 410, IDS, Postfach 5409, D-6800 Mannheim 1, Federal Republic of Germany.

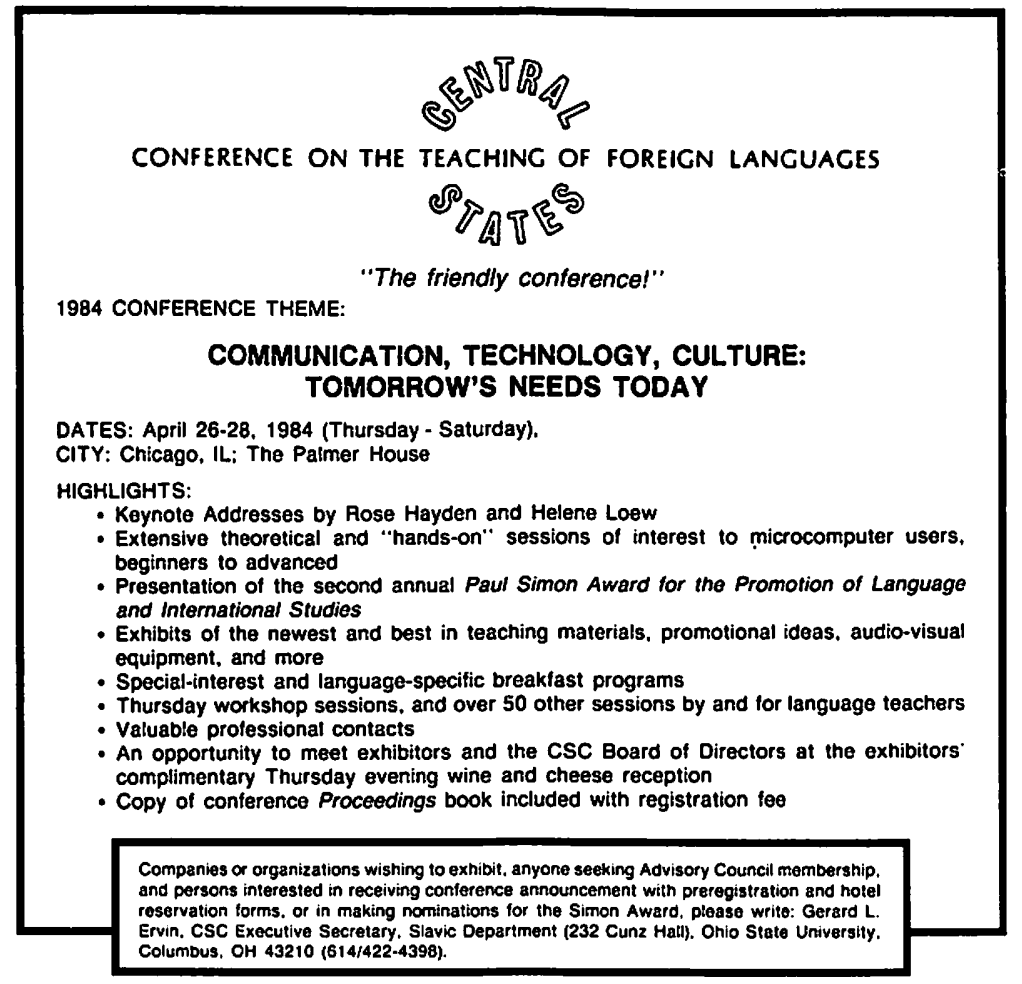




\section{ACKNOWLEDGEMENT}

The Editor-in-Chief of the NALLD JOURNAL along with the Executive Board of Directors of the International Association for Learning Laboratories wish to publicly extend their gratitude to the sustaining members whose names and addresses are listed below for their continued support of the organization for the 1982-83 publishing year. In addition to public acknowledgement of their support, IALL grants to the sustaining members the privilege of using the IALL official membership list for commercial purposes. IALL members who desire that their names not be publicly distributed should communicate their desire directly to the Editor-in-Chief.

ELS Educational Media Division Polyline Corp

12400 North Santa Fe

Oklahoma City, OK 73114

1233 Rand Road

Des Plaines, IL 60016

\section{Tandberg of America \\ Labriola Court \\ POB 58 \\ Armonk, NY 10504}

\section{CORRECTIONS}

In Vol. $17 \mathrm{nr} 3 / 4$, page 30 , the article VIDEO REVIEW by Jackie Tanner gave the Wisconsin Foundation for Vocational, Technical and Adult Education, Inc. (WFVTAE) as the source for a French grammar series. We have received information from that organization that they do not have training via interactive computer/video systems. For more information, contact the WFVTAE at 5402 Mineral Rd, Madison, WI 53705. The Journal expresses its regret for any inconvenience the original article may have caused. 